\title{
POSSIBLE ZOONOTIC VIRAL THREATS ASSOCIATED WITH BATS IN SOUTHERN UKRAINE
}

\author{
Oksana Yurchenko, Dmytro Dubina, Dmytro Sokolovskyi, Oleksandr Gaidash \\ SB «Mechnikov Ukrainian Anti-Plague Research Institute of the Ministry of Health of Ukraine» \\ 2/4, Tserkovna St., Odesa, 65003, Ukraine \\ E-mail:oksyurch@ukr.net
}

\begin{abstract}
Possible zoonotic viral threats associated with bats in southern Ukraine. - Yurchenko, O., Dubina, D., Sokolovskyi, D., Gaidash, O. - The paper is devoted to evaluation of some bat species inhabiting Ukraine as potential reservoir hosts of highly dangerous viruses including lyssaviruses, MERS-CoV-related coronaviruses, and arboviruses. Repeated catches of bats by a domestic cat were described. Laboratory examination of the caught bats did not detect infection with coronaviruses or arboviruses such as West Nile, tick-borne encephalitis, Crimean-Congo hemorrhagic fever, Tribec and Uukuniyemi viruses. The analysis of the literature showed the possibility of persistence of dangerous viruses among examined bat species. The fact that domestic cats may prey on bats that are potential reservoir hosts of dangerous viruses should be considered as a risk factor for infection of humans and cats with lyssaviruses causing rabies, and infection of humans with coronaviruses that may be associated with severe respiratory diseases.
\end{abstract}

Key words: Chiroptera, arboviruses, coronaviruses, lyssaviruses, pets, biological risk for humans.

\begin{abstract}
Можливі загрози, пов'язані з зоонозними вірусами кажанів на півдні України. - Юрченко, О., Дубина, Д., Соколовський, Д., Гайдаш, О. - Повідомлення присвячено оцінці ролі деяких видів кажанів, що населяють південь України, як потенційних резервуарів особливо небезпечних вірусів ліссавірусів, коронавірусів, споріднених з вірусом близькосхідного респіраторного синдрому, та арбовірусів. Описано повторні випадки вилову кажанів свійським котом. Лабораторне обстеження відловлених котом кажанів не виявило наявності у них коронавірусів і таких арбовірусів, як віруси Західного Нілу, кліщового енцефаліту, Кримської-Конго геморагічної гарячки, Трибеч та Уукуніємі. Проведений аналіз даних з літератури свідчить про можливость персистенції небезпечних вірусів серед обстеженних видів кажанів. Той факт, що домашні коти можуть полювати на кажанів як потенційних резервуарів (носіїв) небезпечних вірусів, слід розглядати як фактор ризику для зараження людей та котів ліссавірусами, які викликають сказ, а людей — коронавірусами, що можуть спричиняти важкі респіраторні захворювання.
\end{abstract}

Ключові слова: Chiroptera, арбовіруси, коронавіруси, ліссавіруси, домашні тварини, біологічний ризик для людей.

\section{Introduction}

Bats are mammals of the order Chiroptera - the second largest order of mammals (following rodents), representing about $20 \%$ of all classified mammal species worldwide. Bats are present throughout the world except for extremely cold regions. They occupy various ecosystems and are known as carriers and potential reservoir hosts of human-pathogenic and zoonotic viruses such as Ebolaviruses, Marburg, Nipah, Hendra, Severe acute respiratory syndrome coronavirus (SARS$\mathrm{CoV}$ ), Middle East respiratory syndrome coronavirus (MERS-CoV), rabies, and other lyssaviruses (Memish et al., 2013; Kohl, Kurth, 2014; Han et al., 2015). Despite significant advances in the study of bats as reservoir hosts of human-pathogenic viruses in the world, Ukraine remains a "white spot" on the map. At the time, hardly anything is known about human-pathogenicity of European bat viruses apart from lyssaviruses that cause rabies (Kohl, Kurth, 2014).

Our institute is involved into an arbovirus surveillance program and the laboratory has almost 30 years experience of detection of highly dangerous viruses of human interest, predominantly arbo- 
viruses (arthropod-borne viruses), and has recently started to perform diagnostics of coronaviruses. Generally, the laboratory conducts testing of ticks and mosquitoes, sometimes also samples from small mammals and birds. Bats have never been objects of our examinations, mainly because all European species of bats are protected by the International Union for Conservation of Nature (IUCN) Red List of Threatened Species, Convention on the Conservation of Migratory Species of Wild Animals (CMS) including Agreement on Conservation of Populations of European Bats (EUROBATs), and national regulations (Red Data Book of Ukraine) that restricted the works with these animals. Therefore, when the bats captured and killed by a domestic cat were delivered to the laboratory, it was decided to examine these samples to detect arbo- and coronaviruses.

The aim of the study was to evaluate threats associated with behavioral features of domestic cats that may prey on bats - potential carriers and reservoir hosts of pathogenic viruses.

\section{Material and methods}

The trigger event to start this study was a fact of catching a bat by a domestic cat in the historical center of Odesa city, Ukraine, in April 2, 2013. The three years old male cat was living in an apartment on the first floor of an old two-storey building and had free access outside. The apartment door opened directly to the yard. A dead bat was found by the owner of the cat on the entrance porch of the apartment. The bat was delivered to the institute, where it was defined based on morphology (Zagorodniuk, 2002) as a serotine bat (Eptesicus serotinus), and its inner organs (brain, kidneys, heart, lungs) were taken for examination. More eight bats were caught by the same cat at the same place: four common noctules (Nyctalus noctula) in July-August 2013, two Kuhl's pipistrelles (Pipistrellus kuhlii) in September 2013, and two Nyctalus sp. (likely, N. noctula) in August 2015. In total, nine bats were catched by the domestic cat at the same place during the period of 2 years and 4.5 months. Brain, kidneys, heart, and lungs from all the bats, and additionally liver, spleen, and cloacal swab from Nyctalus sp. were taken for further testing for arboviruses and coronaviruses.

In total, 17 samples of inner organs (brain, kidneys, heart, lungs) from 7 bats $-E$. serotinus (1), N. noctula (4), P. kuhlii (2) caught in 2013 were tested in reverse-transcriptase polymerase chain reaction (RT-PCR) to detect RNA of coronaviruses (CoV), West Nile (WNV) and tick-borne encephalitis (TBEV) viruses (family Flaviviridae), Crimean-Congo hemorrhagic fever (CCHFV) and Uukuniemi (UUKV) viruses (family Bunyaviridae), and Tribec (TRBV) virus (family Reoviridae).

RNA extraction was carried out with ethanol precipitation method using RIBO-prep kit (AmpliSens biotechnologies, Russia).

For WNV detection, a one-step real time reverse transcriptase polymerase chain reaction (RTPCR) was used (AmpliSens-WNV-FL kit, AmpliSens biotechnologies, Russia). Internal control was included for each sample to exclude amplification inhibition. Thermal cycling was performed in Applied Biosystems 7500 System at $50^{\circ} \mathrm{C}$ for $30 \mathrm{~min}$, followed by $95^{\circ} \mathrm{C}$ for $15 \mathrm{~min}$, then 5 cycles at $95^{\circ} \mathrm{C}$ for $5 \mathrm{~s}, 56^{\circ} \mathrm{C}$ for $30 \mathrm{~s}, 72^{\circ} \mathrm{C}$ for $15 \mathrm{~s}$, and 40 cycles at $95^{\circ} \mathrm{C}$ for $5 \mathrm{~s}, 56^{\circ} \mathrm{C}$ for $30 \mathrm{~s}$ with fluorescent signal detection, and at $72^{\circ} \mathrm{C}$ for $15 \mathrm{~s}$.

For detection of coronaviruses two RT-PCR protocols recommended by WHO and targeting RNA-dependent RNA polymerase (RdRp) and nucleoprotein $(\mathrm{N})$ genes were used (Corman et al., 2012). Shortly, conventional nested PCR assays were conducted as described earlier using SuperScript III One Step RT-PCR System with Platinum Taq DNA Polymerase and Platinum Taq DNA Polymerase kits (Invitrogen, USA) (Corman et al., 2012).

Thermal cycling was performed in Applied Biosystems 2720 Thermal Cycler in two rounds at $94^{\circ} \mathrm{C}$ for 3 min followed by 45 cycles at $94^{\circ} \mathrm{C}$ for $15 \mathrm{~s}, 56^{\circ} \mathrm{C}$ for $15 \mathrm{~s}, 72^{\circ} \mathrm{C}$ for $30 \mathrm{~s}$, with a terminal elongation step at $72^{\circ} \mathrm{C}$ for $2 \mathrm{~min}$. The first round additionally included the reverse transcription step at $50^{\circ} \mathrm{C}$ for $20 \mathrm{~min}$ before amplification.

For detection of TBEV, CCHFV, TRBV, and UUKV samples of cDNA were synthesized with Maxima First Strand cDNA Synthesis Kit for RT-PCR (Thermo Fisher Scientific Inc., USA) according to thermal program including primarily incubation at $25^{\circ} \mathrm{C}$ for $10 \mathrm{~min}$, cDNA synthesis at $50^{\circ} \mathrm{C}$ for $30 \mathrm{~min}$, and reaction termination at $85^{\circ} \mathrm{C}$ for $5 \mathrm{~min}$. 
Table 1. Primers and probes used for the detection of TBEV, CCHFV, TRBV and UUKV RNA

Таблиця 1. Праймери і зонди, використані для виявлення РНК вірусів кліщового енцефаліту, КримськоїКонго геморагічної гарячки, Трибеч і Уукуніємі

\begin{tabular}{l|l|l}
\hline Virus & Name of primer/ probe & Sequence $\left(5^{\prime} \rightarrow 3^{\prime}\right)$ \\
\hline \multirow{2}{*}{ TBEV } & $\begin{array}{l}\text { European TBEV forward primer } \\
\text { European TBEV reverse primer }\end{array}$ & $\begin{array}{l}\text { CTGTTTGGAAAGGGTAGCATTGT } \\
\text { GTACACATGTCCTGTGGCTTTCTT }\end{array}$ \\
& European TBEV probe & FAM-AAGGCCGGCTTGTGAGG-MGB \\
\hline CCHFV & forward primer & GGAGTGGTGCAGGGAATTTG \\
& reverse primer & CAGGGCGGGTTGAAAGC \\
& probe & FAM-CAAAGGCAAGTACATCAT-MGB \\
\hline TRBV & forward primer rt-Tr-4f & ATTCC(C/T)CCAGAGGACATGTAC \\
& reverse primer rt-Tr-4r & GCCTTGATTGCGACATCCCG \\
& probe Tr-prb4 & FAM-TGCGGCGTCGTATACTGCATCTGCCCGC-TAMRA \\
\hline \multirow{2}{*}{ UUKV } & forward primer UKUV-M-1417-F & ATGTGGATGAAGGACCCAGA \\
& reverse primer UKUV-M-1593-R & TCTGACTGGAGGCTGTTACA \\
\hline
\end{tabular}

Obtained cDNA samples were tested in laboratory established real-time PCR assays for detection of TBEV, CCHFV, and TRBV, and conventional PCR assay for detection of UUKV.

In real-time PCR assays for detection of TBEV, CCHFV, and TRBV RNA Maxima Probe qPCR Master Mix (2x) (Thermo Fisher Scientific Inc., USA) and virus-specific primers and probes were used (tab. 1). Thermal cycling was performed in Applied Biosystems 7500 System at $95^{\circ} \mathrm{C}$ for $10 \mathrm{~min}$, and then 40 cycles at $95^{\circ} \mathrm{C}$ for $15 \mathrm{~s}, 60^{\circ} \mathrm{C}$ for $31 \mathrm{~s}, 72^{\circ} \mathrm{C}$ for $30 \mathrm{~s}$.

UUKV conventional PCR included Maxima Hot Start Green PCR Master Mix (2X) (Thermo Fisher Scientific Inc., USA) and virus-specific primers to the M segment of genome (table 1). Thermal cycling was performed in Applied Biosystems 2720 Thermal Cycler at $95^{\circ} \mathrm{C}$ for $4 \mathrm{~min}$, followed by 40 cycles at $95^{\circ} \mathrm{C}$ for $30 \mathrm{~s}, 53^{\circ} \mathrm{C}$ for $30 \mathrm{~s}$, with a terminal elongation step at $72^{\circ} \mathrm{C}$ for $15 \mathrm{~min}$.

As positive control samples European TBEV RNA oligonucleotide ${ }^{1}$, CCHFV RNA oligonucleotide $^{2}$, RNA samples of TBEV, TRBV or UUKV from the institute collection were used.

\section{Results and their discussion}

In the result of PCR testing, RNA of CoV, WNV, TBEV, CCHFV, TRBV, and UUKV were not detected, however a small amount of samples does not allow excluding the infection of E. serotinus, $N$. noctula, and $P$. kuhlii bats inhabiting Ukraine with these viruses.

Currently it is known about infection of bats inhabiting Ukraine by two viruses with recognized or potential pathogenicity for humans - lyssavirus (family Rhabdoviridae) and betacoronavirus (family Coronaviridae). European bat lyssavirus type 1, lineage/subtype a (EBLV-1a) was identified in the particoloured bat (Vespertilio murinus) in Volyn region in 1987 (Amengual et al., 1997; Davis et al., 2005). More 16 rabies cases in bats were recorded in different regions of Ukraine in 20012005, 2007, 2008, 2010, 2011, 2013, 2014 (WHO Rabies Bulletin Europe, 15.08.2016). Lineage 2c betacoronavirus related to Middle East respiratory syndrome coronavirus - MERS-CoV (primarily named EMC/2012 or hCoV-EMC/2012), causing severe respiratory disease in humans, was detected in Nathusius' pipistrelle (Pipistrellus nathusii) caught in Kyiv region in 2011 (Annan et al., 2013).

According to research carried out in other countries, the bat species caught in Odesa are reservoir hosts of dangerous and potentially dangerous viruses. Lyssaviruses were detected in E. serotinus in Denmark, France, Germany, Netherlands, Poland, Slovakia, and Spain (Davis et al., 2005). Occurrence of betacoronavirus lineage 2c was documented in Italy in E. serotinus (De Benedictis et al., 2014), N. noctula and P. kuhlii (Lelli et al., 2013).

\footnotetext{
${ }^{1} 5$ '-cuguuuggaaaggguagcauuguggccugugucaaggccggcuugugaggccaaaaagaaagccacaggacauguguacg-3'

${ }^{2} 5$ '-gaugucccccagggeggguugaaagccaugauguacuugccuuugacaaauucccugcaccacuccacauguucacggc-3,
} 
The infection of bats with arboviruses of the family Bunyaviridae was revealed among N. noctula in the Czech Republic and Kyrgyzstan (Issyk-Kul virus) (Database bat viruses, 15.08.2016), and among $P$. kuhlii in Italy (Toscana virus) (Baggieri et al., 2015).

The described cases of catching bats by a domestic cat are another confirmation of the possibility of the participation of cats in the EBLV transmission chain "bat $\rightarrow$ cat $\rightarrow$ human" (Zagorodniuk, Korobchenko, 2007). A confirmed rabies case in a domestic cat was identified in 3-4 months after contacting with a bat in Rovenki, Ukraine, 2006 (ibid.). In another case, lyssavirus infection was detected in the bat caught by a cat after it flew into an apartment of a five-storey building in the center of Luhansk city, Ukraine, 2007 (ibid.). Two suspected cases of EBLV-1 spillover transmission from bats to domestic cats were identified in France in 2003 and 2007 (Dacheux et al., 2009). Therefore, the combination of high-level prevalence of lyssavirus infection among bat population in anthropocoenoses with behavioral features of domestic cats preying on bats may cause the lyssavirus spillover transmission from bats to domestic cats and increase the risk of rabies in humans.

\section{Conclusions}

Thereby, the presence of bat species - potential reservoir hosts of dangerous viruses such as lyssaviruses, MERS-CoV-related coronaviruses, and arboviruses, may pose a threat for human health in Ukraine. Described cases of catching bats by domestic cats may be an additional factor contributing into transmission of viruses from bats to cats, and then to humans. This fact should be considered at risk assessments of occurrence of rabies among humans and cats and of severe respiratory syndrome associated with coronaviruses in humans.

\section{Acknowledgements}

The authors kindly thank to V. G. Dedkov, Central Research Institute for Epidemiology, Russian Inspectorate for Protection of Consumer Rights and Human Welfare (Moscow, Russia) for providing the TRBV primers and probe sequences.

\section{Література • References}

Amengual, B., Whitby, J. E., King, A. et al. Evolution of European bat lyssaviruses // Journal of General Virology. 1997. Vol. 78. P. 2319-2328.

Annan, A., Baldwin, H. J., Corman, V. M. et al. Human Betacoronavirus 2c EMC/2012-related viruses in bats, Ghana and Europe // Emerging Infectious Diseases. 2013. Vol. 19, № 3. P. 456-459.

Baggieri, M., Marchi, A., Bucci, P. et al. Genetic variability of the S segment of Toscana virus // Virus Research. 2015. Vol. 200. P. 35-44.

Corman, V. M., Muller, M. A., Costabel, U. et al. Assays for laboratory confirmation of novel human coronavirus (hCoVEMC) infections // Euro Surveill. 2012. Vol. 17, № 49. pii=20334. 9 p. https://goo.gl/htc1h4

Dacheux, L., Larrous, F., Mailles, A. et al. European bat lyssavirus transmission among cats, Europe // Emerging Infectious Diseases. 2009. Vol. 15, № 2. P. 280-284.

Database bat viruses. 15.08.2016. https://goo.gl/PXfL14

Davis, P. L., Holmes, E. C., Larrous, F. et al. Phylogeography, population dynamics, and molecular evolution of European bat lyssaviruses // Journal of Virology. 2005. Vol. 79, No. 16. P. 10487-10497.

De Benedictis, P., Marciano, S., Scaravelli, D. et al. Alpha and lineage $\mathrm{C}$ betaCoV infections in Italian bats // Virus Genes. 2014. Vol. 48. P. 366-371.

Han, H.-J., Wen, H., Zhou, C.-M. et al. Bats as reservoirs of severe emerging infectious diseases // Virus Research. 2015. Vol. 205. P. 1-6.

Kohl, C., Kurth, A. European bats as carriers of viruses with zoonotic potential // Viruses. 2014. Vol. 6. P. 3110-3128.
Lelli, D., Papetti, A., Sabelli, C. et al. Detection of coronaviruses in bats of various species in Italy // Viruses. 2013. Vol. 5. P. 2679-2689.

Memish, Z. A., Mishra, N., Olival, K. J. et al. Middle East respiratory syndrome coronavirus in bats, Saudi Arabia // Emerging Infectious Diseases. 2013. Vol. 19, No. 11. P. 18191823.

Schountz, T. Immunology of bats and their viruses: challenges and opportunities // Viruses. 2014. Vol. 6. P. 4880-4901.

WHO Rabies Bulletin Europe. Information surveillance research. 2016 (15.08.2016). www.who-rabies-bulletin.org

Zagorodniuk, I. Keys to identification of bats // Bats of Ukraine and adjacent countries: a guide for field investigations / Zagorodniuk, I., Godlevska, L., Tyshchenko, V., Petrushenko, Ya. // Proceedings of the Theriological School. 2007. Vol. 3. P. 64-84. (in Ukr.)

[Загороднюк, I. Ключі до визначення кажанів // Кажани України та суміжних країн: керівництво для польових досліджень / Загороднюк, І., Годлевська, Л., Тищенко, В., Петрушенко, Я. // Праці Теріологічної школи. 2007. Вип. 3. С. 64-84.]

Zagorodniuk, I. V., Korobchenko, M. A. Bats and lyssaviruses: analysis of cases from Ukraine and hypotheses of rabies migrations into anthropocoenoses // Visnyk Luh. Ped. Univ. (Ser. Biol.). 2007. No. 16. P. 104-116. (in Ukr.)

[Загороднюк, I. В., Коробченко, М. А. Кажани та ліссавіруси: аналіз даних з України та гіпотези міграції сказу в антропоценози // Вісник Луганського пед. університету ім. Т. Шевченка. Серія Біологічні науки. 2007. № 16. C. 104-116.] 